\title{
ANTIGENOTOXIC EFFECTS OF MELATONIN AGAINST CHROMOSOME DAMAGE INDUCED BY 7,12- \\ DYMETHYLBENZ(a)ANTHRACENE
}

\author{
Sh. M. A. Omar ${ }^{1}$ \\ Researcher \\ B. M.A. Mohammed ${ }^{2}$ \\ Assist. Prof.
}

1. Department of Basic Science, College of Agriculture, University of Duhok, Duhok, Iraq.

2. Department of Biology, College of Science, University of Duhok, Duhok, Iraq.

shimal.omar@uod.ac_bushra.mohammed@uod.ac

\section{ABSTRACT}

The carcinogen 7,12-dimethylbenz(a)anthracene (DMBA) is a model of Polyaromatic hydrocarbons (PAHs) which is metabolized to DMBA-trans-3,4-diol, an intermediate inductive of DNA mutations through alteration of DNA base pairs, initiation of chronic inflammation and excessive production of Reactive Oxygen Species which is very toxic substances in tissue. This study was aimed to investigate the preventive effects of Melatonin. DNA damage was induced by topical treatment of DMBA to the shaven part of mice skin. Animals injected with melatonin $(10 \mathrm{mg} / \mathrm{kg}$ ) intraperitoneally. mice bone marrow cells were used for the determination of chromosomal aberrations, micronuclei and the percentage of mitotic index. DMBA induced significant elevations in structural chromosome abnormalities, micronuclei, and caused a significant decreases in the mitotic index. The pre-treatment group (Me + DMBA) greatly reduced the number of CA and enhanced MI frequency compared to DMBA treated animals. statistical analysis showed that the number of induced Di-MN and Tri-MN in pre and post treatment groups were decreased significantly compared with the positive control.

Keywords: Genotoxicity; Mutation; oxidative stress; polyromantic hydrocarbons .

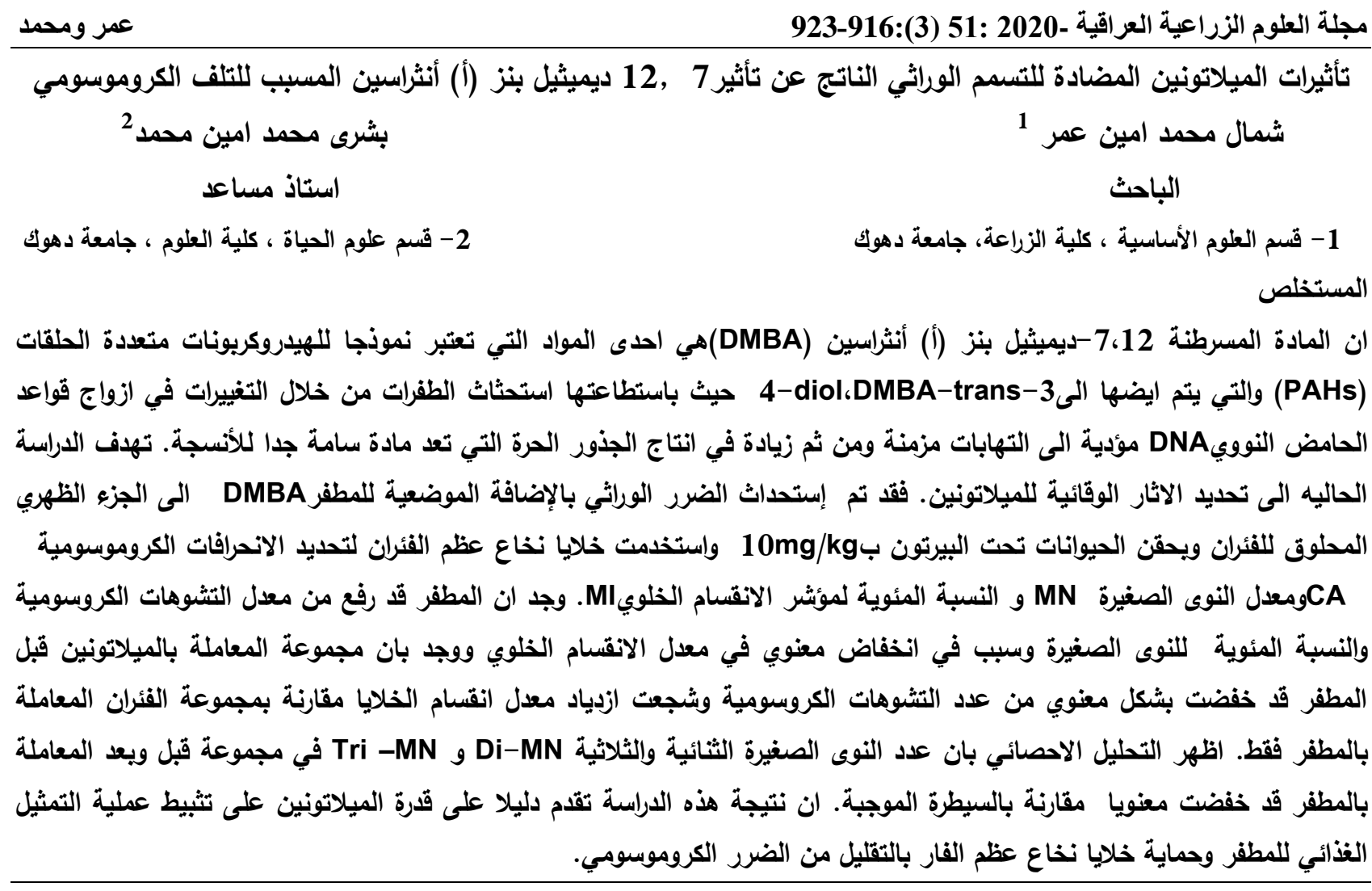

الكلمات المفتاحية: السمية الوراثية؛ الطفرات؛ الضغط التأكسدي؛ ثنائي ميثيل بنز (أ) أنثراسين؛ الحماية. 


\section{INTRODUCTION}

Melatonin is $\mathrm{N}$-acetyl 5 methoxytryptamine, which is a mammalian pineal gland hormone, but it is also known to be synthesized in different other organs, tissues, and cells (23) Melatonin is critical for the regulation of circadian and seasonal changes in various aspects of physiology, neuroendocrine functions (15), In addition to its anti-tumor and oncostatic activity $(4,28)$ and ability to stimulate the immune system, apart from the above functions; melatonin possesses strong antioxidant activity by which it protects cells, tissues and organs from the oxidative damage (17) Many melatonin receptors are found in the body which explains its multiple biological functions, acting both centrally and peripherally in a wide variety of target systems (5), via its receptors, melatonin exerts effects on the secretion of various other hormones, either directly or indirectly by influencing the circadian multioscillator system (10). Melatonin penetrates cell membranes easily, because it has a lipophilic structure so can be found in any cellular compartment , preferentially localized inside the nucleus and can protect nuclear DNA from oxidative damage caused by ROS, especially the hydroxyl radical $(\bullet \mathrm{OH})$, Oxidative damage potentially attacks macromolecules such as DNA, RNA, lipids and proteins. DNA damage produce, DNA - base modifications which involved in enhancing normal cells toward malignant proliferation $(4,22)$. Melatonin may enhance cellular defenses against oxidative stress of antioxidant enzymes such as glutathione peroxidase, catalase and superoxide dismutase (21), all leading to a decrease in DNA damage by interacting with double-stranded DNA and promoting its stability and integrity $(35,25)$.On the other hand, (DMBA) has been shown to induce mutations , It is metabolized by epidermal Langerhans cells to DMBA-trans-3,4-diol, an intermediate inductive of DNA mutations through alteration of DNA base pairs, initiation of chronic inflammation and excessive generation of (ROS), $(20,34)$, which in turn participates in transforming the normal cells to malignant pathways $(26,6)$. Because melatonin has excellent antioxidative properties, there is a likely possibility that melatonin would protect against the toxicity of DMBA. The objective of this study was undertaken to evaluate the effects of melatonin against the genotoxicity induced by DMBA in mice bone marrow cells using the chromosomal aberrations, mitotic index and micronucleus test as a dependent cytogenetic endpoints.

\section{MATERIALS AND METHODS}

\section{Chemicals}

Melatonin ,7,12-Dimethylbenz(a)anthracene (DMBA) and colchicine was supplied from ACROS organics Company. Melatonin was prepared in a minimum volume of $1 \%$ absolute ethanol and distal water to reach a concentration of $10 \mathrm{mg} / \mathrm{kg}$ of body weight (b.w.) then administered intraperitoneally. A fresh melatonin solution was prepared each third day. DMBA (100 mg/100 mL of acetone) was applied topically to the shaven part of mice skin. All other chemicals were of the highest analytical grades which were commercially available.

Animals; Male Swiss albino mice Balb/c , weight 25-30 $\mathrm{g}$ were obtained from the animal house colony of Science College, University of Duhok-Iraq. Animals were kept under a 12-h light/dark cycle, temperature $25 \pm 2{ }^{\circ} \mathrm{C}$. with food and water ad libitum. The protocol is in accordance with the Ethics Principles for Animal Research adopted by Duhok University, College of Veterinary Medicine, Iraq.

\section{Experimental design}

This study included two experiments: the first included the following groups: Animals of the first group were injected intraperitoneally with $0.5 \mathrm{ml}$ of phosphate buffer saline (PBS) daily for 14 days and used as negative control. Animals of the second group, the positive control were applied once topically to the shaven part of mice skin with $0.5 \mathrm{ml}$ of DMBA (100 mg/100 mL of acetone). While animals of group three were administered intraperitoneally with melatonin $10 \mathrm{mg} / \mathrm{kg}$ of body weight (b.w.) during the dark period for 14 consecutive days, group four: (Pre- DMBA treatment) animals were administrated with melatonin $10 \mathrm{mg} / \mathrm{kg}$ for 14 days before treating with DMBA at 15th day. Group five: (PostDMBA treatment) animals treated with a single dose of DMBA once (1 day) and then 
administrated with melatonin $10 \mathrm{mg} / \mathrm{kg}$ for 14 consecutive days. At the end of the experiment, the mice of each group were sacrificed by cervical dislocation and samples of bone marrow were taken for cytogenetic analysis (MI and CA). For the second experiment ,the same experimental design mentioned above was fallowed to calculate the number of polychromatous erythrocytes for the presence of micronuclei $(\mathrm{MN})$.

\section{Cytogenetic study}

Mitotic index (MI) assay: For analysis of Mitotic Index (MI), 1000 cells/animal were scored and expressed in percentages; the slides were examined under light microscope with (40x) power, and 1000 of the divided and nondivided cells were counted and the percentage rate was calculated for only the divided ones according to the equation : MI $\%=$ No. of dividing cells $(\mathrm{P}+\mathrm{M}+\mathrm{A}+\mathrm{T}) /$ T Total No. of dividing cells + No. of non- dividing cells (1000) cells $\}$ X 100 , where $(\mathrm{P}+\mathrm{M}+\mathrm{A}+\mathrm{T})$ is the sum of all cells in phase as prophase, metaphase, anaphase and telophase, respectively (3).

\section{Chromosomal aberration (CA) assay}
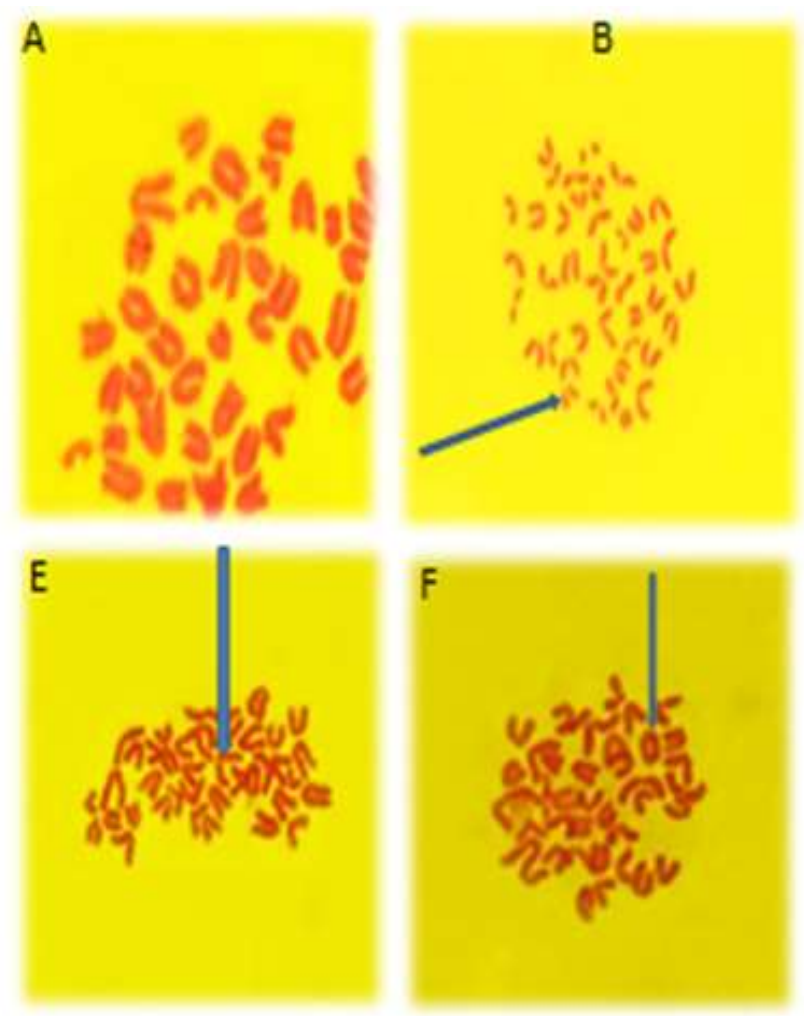

To detect the presence of CA, all treated mice were intraperitoneally injected with $1 \mathrm{ml}$ of ( $4 \mathrm{~g} / \mathrm{kg}$ bow.) colchicine, three hours later the injected mice were sacrificed by cervical dislocation. Both the femurs from the sacrificed mice were fleshed out from the muscles. The femurs were then rinsed with 5 $\mathrm{ml} 0.075 \mathrm{M} \mathrm{KCl}$ solution in a centrifuge tube. The tube was then incubated at $37^{\circ} \mathrm{C}$ for 20 minutes. After incubation, centrifugation at $1000 \mathrm{rpm}$ for 10 minutes was carried out. Supernatant was discarded and fresh Carnoy's fixative was added (3:1 methanol: acetic acid). The process of centrifugation was repeated three times. Bone marrow is the target tissue in this test since it is a highly vascularized tissue and it contains a population of rapidly cycling cells that can be readily isolated and processed. Chromosome slides were prepared by dropping the cell suspension onto cleaned slides, which were flame dried and all slides were coded and stained in dilute Giemsa solution. The microscopic observations performed with a magnification of $100 \times$ oil immersion. Hundred well spread metaphase were scored per animal (500 metaphase per treatment group) at random (7).
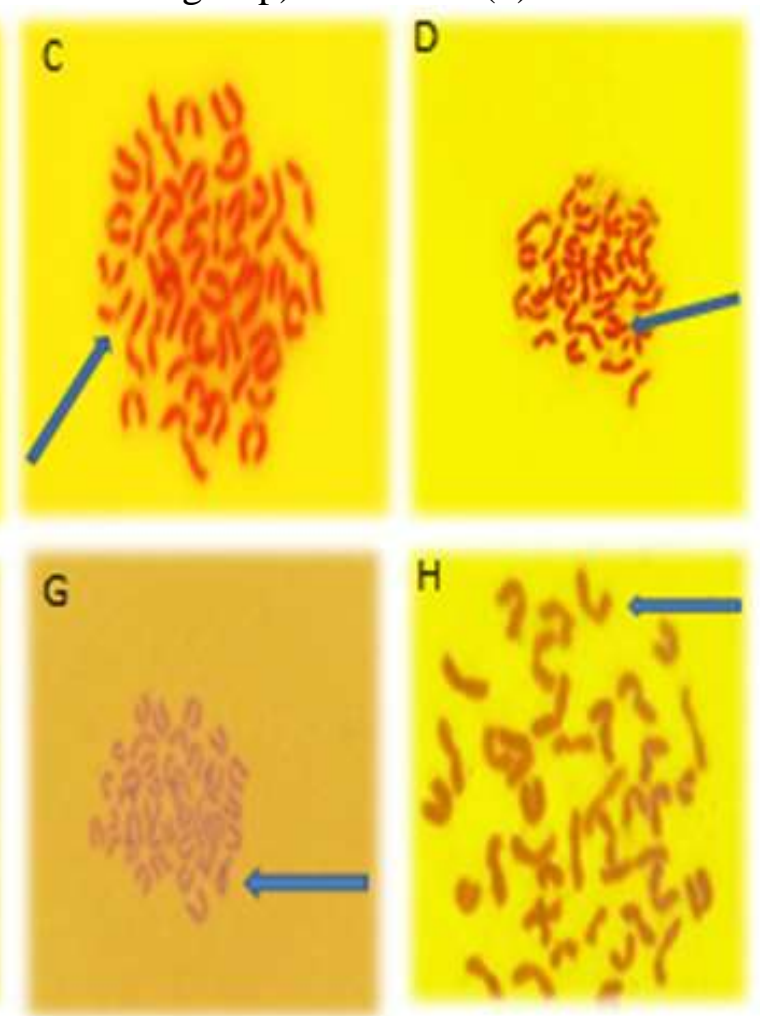

Figure 1. Metaphases from mice treated with DMBA showing different types of structural chromosomal aberrations. A: Normal chromosomes B: Centromere break C: Chromosome breaks D: Acentric fragments E: gap in chromosome, F: Ring chromosome; G: Dicentric chromosome H : Chromatid break. (1000X) . 
Micronucleus test in bone marrow cells (MN): Micronucleus test were analyzed according to Schmid (29), mice bone-marrow cells from both femur of all sacrificed animal were flushed with bovine serum albumin. The obtained cell suspension was centrifuged (1000 rpm for 5minutes), the supernatant was removed and the pellet re-suspended in human albumin serum. Then, a drop of the suspension was smeared on a clean slide, air- dried, fixed
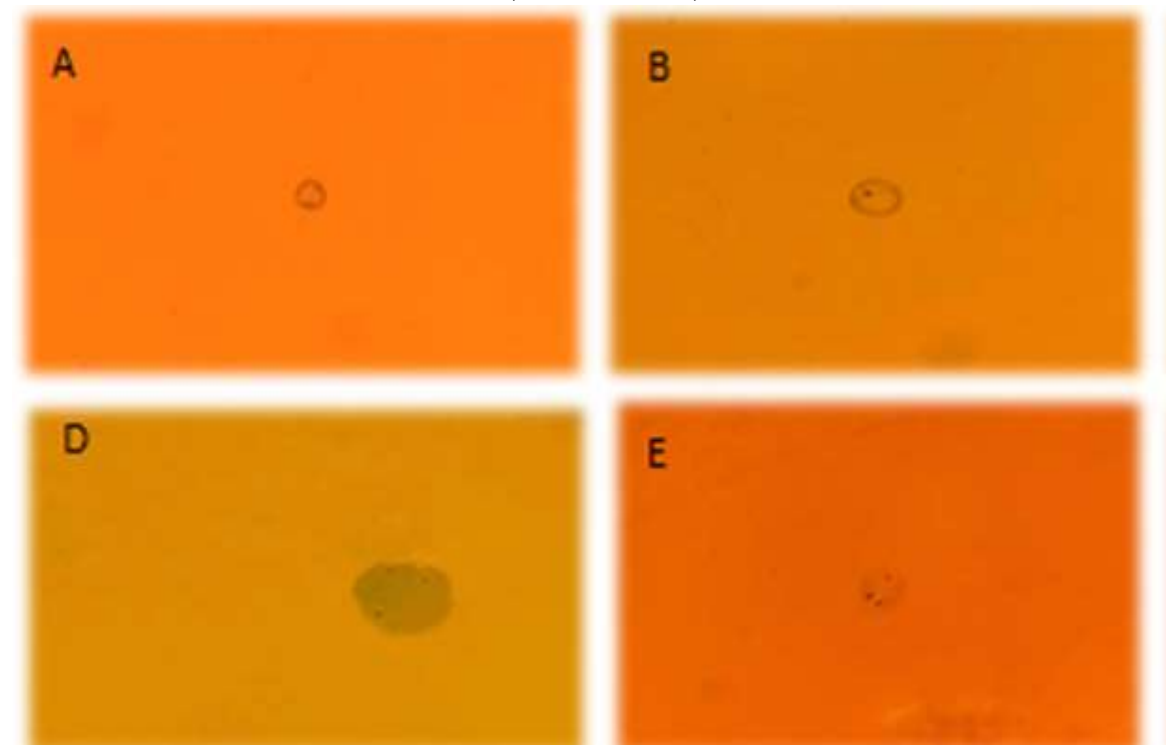

Figure 2. Types of micro-nucleated cell induced by 7,12-dimethylbenz(a)anthracene (DMBA) in male albino mice A: NCE normochromatic B: Monomicronuclei, C: Dimicronuclei, D: Trimicronuclei, E: Tetra micronuclei, F: PCE polychromatic erythrocyte (1000X).

\section{Statistical analysis}

The data submitted to SPSS software (SPSS, 2013) and analyzed using one - way ANOVA according to the following model : Yij $=\mathrm{M}+$ $\mathrm{Gi}+\mathrm{eij}$.

\section{RESULTS AND DISCUSION}

Effect of melatonin on mitotic index and chromosome aberrations induced by DMBA: The slide analysis of a mouse bone marrow smear from the negative control animals revealed a frequency of 7 types of chromosomal aberrations from 500 analyzed cells, the dicentric chromosome, chromosome fragment and gaps recorded the highest aberrant value ,Total aberrations was (364.7) while, melatonin injection did not change the spontaneous incidence of chromosomal aberrations (359.0). Results from animals treated with DMBA represent the highest significant increase in dicentric chromosomes ,chromosome fragment and gaps values and significant increase in total aberrations in comparison to spontaneous mutations detected in intact animals from negative control and in methanol for $5 \mathrm{~min}$ then stained with Giemsa and microscopically examination with a magnification of 100X. About 1000 micronucleated polychromatic erythrocyte (MN- PCE) and polychromatic erythrocyte (PCE) were scored for the presence of micronuclei for each animal. The micronuclei frequency quantification was performed $24 \mathrm{~h}$ after treatment.
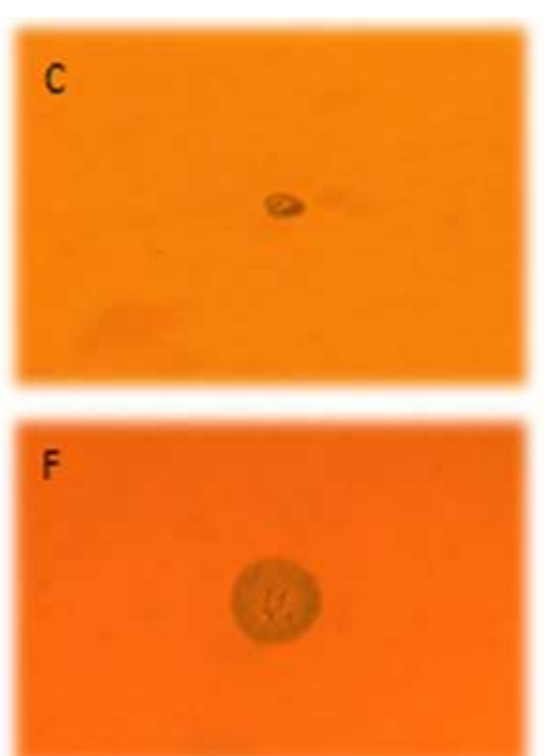
melatonin group (806.7) as shows in Table 1. Inhibition of DMBA -induced mutation was observed when the animals were injected with melatonin 14 consecutive days before treating with DMBA, showing a total number of aberrations (441.0). Moreover the treatment with melatonin for another 14 days after applying DMBA on the dorsal shaved part of the mouse, showed that chromosome breaks and chromatid breaks not affected significantly by melatonin treatment, while melatonin acted its protecting effect on both chromosome fragment and chromosome gaps .Also this treatment reveals a reduction in the total number of aberrations(656.0). This result exhibited a decrease in the number of total aberrant chromosomes in pre and post treatment with melatonin and as expected melatonin was able to inhibit the development of chromosomal aberrations, reducing the total number of aberrant cells in pre-treatment more efficiently than the post treatment with melatonin. Regarding the rate of cells that are in division Statistical analysis Table 1 
indicates that melatonin induced MI similar to that of the negative control (12.07) .while DMBA group present a clear reduction (4.28) and play an inhibitor role for dividing cells

Table 1. Effect of Melatonin and other treatment on chromosome aberration in Male Albino mice

\begin{tabular}{|c|c|c|c|c|c|c|c|c|c|}
\hline $\begin{array}{l}\text { Treatments } \\
\text { (groups) }\end{array}$ & Ch. break & $\begin{array}{l}\text { Chromatid } \\
\text { break }\end{array}$ & $\begin{array}{l}\text { Centromere } \\
\text { break }\end{array}$ & $\begin{array}{l}\text { Di-centric } \\
\text { Chromosom }\end{array}$ & $\begin{array}{l}\text { Ring } \\
\text { chromosor }\end{array}$ & $\begin{array}{l}\text { Chromosome. } \\
\text { Fragment }\end{array}$ & Gape & $\begin{array}{l}\text { Total } \\
\text { aberrations }\end{array}$ & $\begin{array}{l}\text { Divided } \\
\text { percentage } \\
\text { MI\% }\end{array}$ \\
\hline $\begin{array}{l}\text { Negative control } \\
\text { (PBS) }\end{array}$ & $59.0 \pm 1.7 \mathrm{~b}$ & $166.6 \pm 8.9 b$ & $84.7 \pm 4.9 d$ & $18.7 \pm 7.1$ a & $11.0 \pm 2.1 \mathrm{a}$ & $18.7 \pm 5.5 a$ & $6.0 \pm 1.0 a$ & $364.7 \pm 2.3 \mathrm{~d}$ & $12.13 \pm 1.4 \mathrm{a}$ \\
\hline $\begin{array}{l}\text { Positive control } \\
\text { DMBA }\end{array}$ & $176.0 \pm 14.4$ \& & $223.0 \pm 5.1 \mathrm{a}$ & $381.0 \pm 10.7 a$ & $3.7 \pm 0.3 b$ & $13.7 \pm 2.2 \mathrm{a}$ & $6.7 \pm 2.4 \mathrm{~b}$ & $3.0 \pm 0.6 \mathrm{k}$ & $806.7 \pm 4.3 \mathrm{a}$ & $3.27 \pm 0.2 \mathrm{c}$ \\
\hline $\begin{array}{l}\text { Single dose } \\
\text { melatonin } \\
\qquad(10 \mathrm{mg})\end{array}$ & $68.0 \pm 9.6 b$ & $117.3 \pm 0.3 b$ & $162.3 \pm 6.6 \mathrm{c}$ & $3.7 \pm 0.3 b$ & $2.0 \pm 0.0 \mathrm{c}$ & $3.3 \pm 0.7 b$ & $2.7 \pm 0.3 \mathrm{c}$ & $359.0 \pm 4.2 \mathrm{~d}$ & $12.07 \pm 0.7 a$ \\
\hline $\begin{array}{c}\text { Melatonin(10mg) } \\
+ \text { +DMBA }\end{array}$ & $66.7 \pm 5.6 b$ & $139.0 \pm 8.7 b$ & $226.3 \pm 17.4 b$ & $3.3 \pm 0.3 c$ & $2.7 \pm 0.7 b$ & $4.0 \pm 0.6 b$ & $1.3 \pm 0.3 c$ & $441.0 \pm 14.6 c$ & $9.27 \pm 0.6 b$ \\
\hline $\begin{array}{c}\text { DMBA } \\
+(10 \mathrm{mg}) \text { melatoni }\end{array}$ & $164.6 \pm 7.5$ & $228.7 \pm 53.3 \mathrm{a}$ & $252.0 \pm 22.5 b$ & $3.0 \pm 0.6 c$ & $2.3 \pm 0.9 \mathrm{~b}$ & $4.3 \pm 1.9 b$ & $3.7 \pm 0.7 \mathrm{k}$ & $656.0 \pm 27 b$ & $7.33 \pm 0.3 b$ \\
\hline
\end{tabular}

The different letters in the column are significantly different at level $(p<0.05)$.All values given in the table are mean + SEM .PBS: phosphate buffer saline . DMBA: 7,12Dimethylbenzanthracene . total chromosome no= 4000.

Effect of melatonin on the frequency of MnPCEs in bone marrow cells induced by DMBA

Result in Table 2.shows that melatonin had no significant effect on induction of micronuclei in bone marrow cells, which show nearly the same values of negative control .The negative control ,pre and post treatment with DMBA and the total abnormal $\mathrm{MN}$,their frequency value of single-MN did not differ significantly .For Di-Mn, Positive control group recorded the highest value (11.3) compared to other groups, figure 2 . while treatment with melatonin alone showed the lowest significant value . regarding TRI-MN both positive control and pretreatment (melatonin + DMBA)recorded the highest significant value compared to both melatonin alone and post treatment (DMBA+Melatonin), while negative control was intermediate. Tetra-MN recorded the highest value when treated with DMBA then melatonin (DMBA+ melatonin) and didn't differ significantly from positive control. But melatonin alone and pretreatment differ significantly from positive group. It could be noticed from Table 2 that DMBA + melatonin group recorded significantly the highest value of Poly-MN, while the pretreatment group (Melatonin+DMBA) revealed the lowest value of Poly-MN, The remaining groups were intermediate. Total MN percentage result indicated that DMBA increases its value; where the pre and post treatment decreases the number of MnPCEs but not significantly compared to positive group. Both Negative control and melatonin alone treatments, resulted in similar MN values.

Table 2. Effects of Melatonin and other treatments on micronucleus frequency in bone marrow cells of male albino mice

\begin{tabular}{|c|c|c|c|c|c|c|c|c|}
\hline Treatments (groups) & Single- MN & Di-MN & Tri-MN & Tetra-MN & Poly-MN & Total-MN & Total-Normal & $\begin{array}{l}\text { Total MN - } \\
\text { Percentage }\end{array}$ \\
\hline $\begin{array}{c}\text { Negative control } \\
\text { (PBS) }\end{array}$ & $13.0 \pm 2.1 \mathrm{~b}$ & $5.0 \pm 2.9$ bc & $2.67 \pm 0.9 \mathrm{ab}$ & $0.67 \pm 0.3 b$ & $.33 \pm 0.3$ bc & $23.67 \pm 1.8 b$ & $476.33 \pm 1.8 a$ & $4.73 \pm 0.4 b$ \\
\hline $\begin{array}{c}\text { Positive control } \\
\text { DMBA }\end{array}$ & $35.0 \pm 1.7 \mathrm{a}$ & $11.3 \pm 6 . \mathrm{a}$ & $5.00 \pm 0.6 \mathrm{a}$ & $2.67 \pm 0.9 \mathrm{a}$ & $.33 \pm 0.3 \mathrm{ab}$ & $54.33 \pm 5.9 \mathrm{a}$ & $445.67 \pm 5.9 b$ & $10.87 \pm 1.2 \mathrm{a}$ \\
\hline $\begin{array}{c}\text { Single dose } \\
\text { melatonin }(10 \mathrm{mg} / \mathrm{kg}\end{array}$ & $13.0 \pm 2.9 \mathrm{~b}$ & $4.3 \pm 2.5 c$ & $1.33 \pm 0.3 b$ & $1.67 \pm 0.3 b$ & $.67 \pm 0.9 \mathrm{~b}$ & $23.00 \pm 3.1 b$ & $477.00 \pm 3.1 a$ & $4.60 \pm 0.6 b$ \\
\hline $\begin{array}{c}\text { Melatonin } \\
(10 \mathrm{mg} / \mathrm{kg})+\mathrm{DMBA}\end{array}$ & $31.0 \pm 0.6 a$ & $7.0 \pm 4 b$ & $3.00 \pm 1.5 \mathrm{a}$ & $1.67 \pm 0.3 b$ & $1.33 \pm 0.3 c$ & $44.00 \pm 3.2 \mathrm{a}$ & $456.00 \pm 3.2 b$ & $8.80 \pm 0.6 a$ \\
\hline DMBA + melatonin & $31.7 \pm 1.8 \mathrm{a}$ & $8.0 \pm 4.6 \mathrm{~b}$ & $2.00 \pm 0.0 \mathrm{~b}$ & $4.00 \pm 0.6 \mathrm{a}$ & $4.67 \pm 0.9 a$ & $50.33 \pm 2.4 a$ & $449.67 \pm 2.4 b$ & $10.07 \pm 0.5 \mathrm{a}$ \\
\hline
\end{tabular}

The data were expressed as mean \pm SEM, PBS: phosphate buffer saline; N. Co : Negative control; DMBA: 7,12Dimethylbenzanthracene. The different letters in the column are significantly different at level $(p<0.05)$.

This study, was aimed to investigate the protective effect of melatonin on DMBAinduced chromosomal damage and $\mathrm{MN}$ in mice bone marrow cell was investigated. Experiments demonstrate the inhibitory activity of melatonin on DNA damage.This effect appeared as significant decreases in chromosome aberrations induced and cell 
proliferation index, particularly in the case of the pretreatment group used. While statistical analysis showed that the number of induced Di-MN and Tri $-\mathrm{MN}$ in pre and post treatment groups decreased significantly. It is well known that metabolic activation of DMBA may be realized principally by cytochrome P-450 which converts DMBA to form diol epoxides and other toxic such as reactive oxygen species (ROS) (9). Consequences of the damage initiated by these metabolic by products affect a large range of biological reactions, such as alteration of cellular membrane composition, metabolic ,structural proteins, detoxifying enzymes and cellular signaling proteins (18).Chromosomal damage has been reported as a result of binding of diol epoxides to adenine residues of DNA (9). In addition, DMBA metabolism generates reactive oxygen species (ROS), which spread along the generation site or diffuse to outside of the intact cells (27). ROS cause lipid peroxidation directly or indirectly through production of free radicals which damage all biological macromolecules, such as DNA, lipids and proteins leading to increases in mutation frequency, on bone marrow cells $(31,32)$. In fact Melatonin has been documented to prevent oxidative damage in different skin components $(11,16)$ and it revealed protective effects against prooxidative agents $(8,12)$ Similarly, in earlier studies, such short time as days or weeks of melatonin treatment, was sufficient to reverse oxidative damage to macromolecules in animals $(14,13)$. Could be influencing phase I and II drug metabolizing enzymes, (19). And this effect was attributed to the antioxidant properties of the pineal secretory product (24).this property may have an important role in inhibiting the growth of some types of tumors. Melatonin has been reported to suppresses DNA adduct formation by safrole, a naturally occurring carcinogen, in rat livers because of its ability to inhibit cytochrome P-450 mixed function oxidases. (30). The result of this study concerning chromosome aberrations and micronuclei test are in agreement with other studies which showed that melatonin scavenging activity of free radicals could decrease those aberrant and micronuclei induced by Gama- radiation in human lymphocytes, $(33,2,1)$. This may be due to that melatonin is a scavenger only of hydroxyl radicals, which induce chromosome aberrations, thus decreasing this type of damage. The results were, However, revealed that melatonin has anticlastogenic activity. Thus, the presented study demonstrate a reduction in DNA damage induced by DMBA, probably due to melatonin modulating the activity of P-450 and/or to its ability to interact with DMBA electrophilic metabolites. We conclude that melatonin supplement could be considered as an agent to be used as antioxidant for some skin defects caused by Polycyclic aromatic hydrocarbon compounds wide spread in our environment.

\section{REFERENCES}

1. Al-khateeb, S.O., 2016. Aqueous extract of red tea plant (Hibiscus sabdariffa) effect on the lipid profile and glucose in male white rabbits exposed to oxidative stress. Iraqi Journal of Agricultural Sciences, 47(1).326336

2. Badr, F.M., El Habit, O.H.M. and Harraz, M.M., 1999. Radio protective effect of melatonin assessed by measuring chromosomal damage in mitotic and meiotic cells. Mutation Research/Genetic Toxicology and Environmental Mutagenesis, 444(2).367372

3. Becker, W.M., Kleinsmith, L.J., Hardin. J. and Bertoni, G. P. 2009. The World of the Cell. 7th edition. Pearson Benjamin Cummings Publishing, San Francisco

4. Blask, D.E., 2009. Melatonin, sleep disturbance and cancer risk. Sleep medicine reviews, 13(4).257-264

5. Carlberg, C., 2000. Gene regulation by melatonin. Annals of the New York Academy of Sciences, 917(1) .387-396

6. Daniel, F.B. and Joyce, N.J., 1983. DNA adduct formation by 7, 12-dimethylbenz [a] anthracene and its noncarcinogenic 2-fluoro analogue in female Sprague-Dawley rats. Journal of the National Cancer Institute, 70(1).111-118

7. Evans, E.P., Breckon, G. and Ford, C.E., 1964. An air-drying method for meiotic preparations from mammalian testes. Cytogenetic and Genome Research, 3(5).289-294 
8. García, J.J., López.Pingarrón, L., Almeida.Souza, P., Tres, A., Escudero, P., García.Gil, F.A., Tan, D.X., Reiter, R.J., Ramírez, J.M. and Bernal.Pérez, M., 2014. Protective effects of melatonin in reducing oxidative stress and in preserving the fluidity of biological membranes: a review. Journal of Pineal Research, 56(3).225-237

9. Guerin MR, 2012. Energy Sources of polycyclic aromatic hydrocarbons. In: Environment, Chemistry, and Metabolism: 342

10. Hardeland, R., Madrid, J.A., Tan, D.X. and Reiter, R.J., 2012. Melatonin, the circadian multioscillator system and health: the need for detailed analyses of peripheral melatonin signaling. Journal of pineal Research, 52(2).139-166

11. Janjetovic, Z., Nahmias, Z.P., Hanna, S., Jarrett, S.G., Kim, T.K., Reiter, R.J. and Slominski, A.T., 2014. Melatonin and its metabolites ameliorate ultraviolet B-induced damage in human epidermal keratinocytes. Journal of Pineal Research, 57(1).90-102

12. Karbownik, M. and Lewiński, A., 2003. Melatonin reduces fenton reaction-induced lipid peroxidation in porcine thyroid tissue. Journal of Cellular Biochemistry, 90(4).806-811

13. Karbownik, M., Stasiak, M., Zygmunt, A., Zasada, K. and Lewiński, A., 2006. Protective effects of melatonin and indole-3-propionic acid against lipid peroxidation, caused by potassium bromate in the rat kidney. Cell Biochemistry and Function: Cellular biochemistry and its modulation by active agents or disease, 24(6).483-489

14. Karbownik, M.,Tan, D.X., Manchester, L.C. and Reiter, R.J., 2000. Renal toxicity of the carcinogen $\delta$-aminolevulinic acid: antioxidant effects of melatonin. Cancer Letters, 161(1).1-7

15. Kennaway, D.J., Voultsios, A., Varcoe, T.J. and Moyer, R.W., 2002. Melatonin in mice: rhythms, response to light, adrenergic stimulation, and metabolism. American Journal of Physiology-Regulatory, Integrative and Comparative Physiology, 282(2).R358R365

16. Kleszczyński, K., Zwicker, S., Tukaj, S., Kasperkiewicz, M., Zillikens, D., Wolf, R. and Fischer, T.W., 2015. Melatonin compensates
Silencing of Heat Shock Protein 70 and suppresses ultraviolet radiation-induced inflammation in human skin ex vivo and cultured keratinocytes. Journal of Pineal Research, 58(1).117-126

17. Maestroni, G. J., 1993. The immunoneuroendocrine role of melatonin. Journal of Pineal Research, 14(1), pp. $1-10$

18. Marnett, L.J., Riggins, J.N. and West, J.D., 2003. Endogenous generation of reactive oxidants and electrophiles and their reactions with DNA and protein. The Journal of clinical Investigation, 111(5).583-593

19. Melchiorri, D., Ortiz, G.G., Reiter, R.J., Sewerynek, E., Daniels, W.M.U., Pablos, M.I. and Nistico, G., 1998. Melatonin reduces paraquat-induced genotoxicity in mice. Toxicology letters, 95(2):103-108.

20. Modi, B.G., Neustadter, J., Binda, E., Lewis, J., Filler, R.B., Roberts, S.J., Kwong, B.Y., Reddy, S., Overton, J.D., Galan, A. and Tigelaar, R., 2012. Langerhans cells facilitate epithelial DNA damage and squamous cell Carcinoma. Science, 335(6064).104-108

21. Pablos, M.I., Chuang, J.I., Reiter, R.J., Ortiz, G.G., Daniels, W.M., Sewerynek, E., Melchiorri, D. and Poeggeler, B., 1995. Time course of the melatonin-induced increase in glutathione peroxidase activity in chick tissues. Neurosignals, 4(6): 325-330

22. Pan, M.H, C.S. Lai, J.C. Wu, C.T. Ho., 2011.Molecular mechanisms for chemoprevention of colorectal cancer by natural dietary compounds. Mol Nutr Food Res; 55: 32-45

23. Pandi.Perumal, S.R., Srinivasan, V., Maestroni, G.J.M., Cardinali, D.P., Poeggeler, B. and Hardeland, R., 2006. Melatonin: nature's most versatile biological signal?. The FEBS Journal, 273(13).2813-2838

24. Praast, G., Bartsch, C., Bartsch, H., Mecke, D. and Lippert, T.H., 1995. Hepatic hydroxylation of melatonin in the rat is induced by phenobarbital and 7, 12dimethylbenzy [a] anthracene-implications for cancer etiology. Experientia, 51(4):349355

25. Reiter, R.J., Herman, T.S. and Meltz, M.L., 1996. Melatonin and radioprotection from genetic damage: in vivo/in vitro studies with human volunteers. Mutation 
Research/Genetic Toxicology, 371(3-4).221228

26. Reiter, R.J., Tan, D.X., Manchester, L.C. and Tamura, H., 2007. Melatonin defeats neurally-derived free radicals. J. Physiol. Pharmacol, 6.5-22

27. Russo, J., Tay, L.K. and Russo, I.H., 1982. Differentiation of the mammary gland and susceptibility to carcinogenesis. Breast Cancer Research and Treatment, 2(1).5-73

28. Schieber, M. and Chandel, N.S., 2014. ROS function in redox signaling and oxidative stress. Current biology, 24(10).R453-R462

29. Schmid W, 1975.The Micronucleus Test. Mutation Research. Feb; 31(1).9-15

30. Sliwinski, T., Rozej, W., Morawiec-Bajda, A., Morawiec, Z., Reiter, R. and Blasiak, J., 2007. Protective action of melatonin against oxidative DNA damage-chemical inactivation versus base-excision repair. Mutation Research/Genetic Toxicology and Environmental Mutagenesis, 634(1-2), pp.220-227
31. Tan, D.X., Reiter, R.J., Chen, L.D., Poeggeler, B., Manchester, L.C. and BarlowWalden, L.R., 1994. Both physiological and pharmacological levels of melatonin reduce DNA adduct formation induced by the carcinogen safrole. Carcinogenesis, 15(2).215218

32. Thakkar Jalaram H., K. Solanki Himanshu Tripathi Pankaj, and Patel Natvarlal JGK. 2010,Evaluation of Antimutagenic Potential of Annona Squamosa Leaf Extract. International Journal of Biological \& Pharmaceutical Research. 1(2):114-23

33. Valdiglesias, V., Pásaro, E., Méndez, J. and Laffon, B., 2010. In vitro evaluation of selenium genotoxic, cytotoxic, and protective effects: a review. Archives of Toxicology, 84(5).337-351

34. Walentinsson, A. and Levan, G., 2001. Ras gene mutations in 7, 12-dimethylbenz [a] anthracene (DMBA)-induced rat sarcomas. Cancer Letters, 166(1).47-53

35. Webb, S.M. and Puig-Domingo, M., 1995. Role of melatonin in health and disease. Clinical Endocrinology, 42(3).221234. 